Article

\title{
Overcoming Path Dependency in an Industrialised House-Building Company through Entrepreneurial Orientation
}

\author{
Petri Uusitalo ${ }^{1, *(D)}$ and Rita Lavikka ${ }^{2}$ (D) \\ 1 Department of Construction Management and Building Technology, Luleå University of Technology, \\ 97187 Luleå, Sweden \\ 2 Smart Energy and Built Environment, VTT Technical Research Centre of Finland, 02044 VTT/Espoo, Finland; \\ rita.lavikka@vtt.fi \\ * Correspondence: petri.uusitalo@ltu.se
}

Received: 2 January 2020; Accepted: 3 March 2020; Published: 6 March 2020

check for updates

\begin{abstract}
Although it is well-established that industrialised construction can improve construction companies' productivity, the uptake of industrialised ways of working has been slow and traditional construction companies remain unwilling to move towards industrialisation. One key reason is that there is little understanding of how construction companies can overcome path dependency (PD). Drawing on a longitudinal case study looking at an industrialised house-building (IHB) company, this work investigates how entrepreneurial orientation (EO) has influenced the development of a construction company that was able to transform from a traditional construction company to an IHB company over 25 years and to overcome PD in the process. The study found that by focusing on a niche market segment, developing a platform in collaboration with external actors, and an entrepreneurial mindset supported the company in overcoming its PD. However, being the "first-mover" in the industry created new path dependencies that may hinder other companies from entering this specific niche market area and the development of the industry as a whole. This study contributes to the theoretical buildup of EO, PD and strategic orientations of IHB companies, and contributes to practitioners' understanding of IHB companies from a strategic management contingency perspective.
\end{abstract}

Keywords: industrialised house building; construction; path dependency; entrepreneurial orientation; longitudinal case study

\section{Introduction}

What enables companies to survive in the long run? This question has long intrigued strategic management researchers, and many concepts have been introduced to answer it. For example, the concept of entrepreneurial orientation (EO) has been used to explain company-level entrepreneurship, which may enable long-term success [1-3]. However, past decisions have also been found to lock organisations onto pathways that constrain future choices and limit their ability to respond to changes [4-6].

The construction industry can be characterised as mature and slow-to-change [7], and as a setting in which technological change can take several decades [8]. This is due to the path dependency (PD) $[9,10]$ of existing building systems and the industry's characteristics [11]. Therefore, it typically takes two to three decades for construction innovations to achieve significant acceptance [12].

Because demand for construction fluctuates strongly, many traditional house-building companies focus only on short-term goals between projects to gain a competitive advantage [13]. This coping mechanism suppresses innovation and hampers companies' long-term success, as explained by Dubois 
and Gadde [14]. Broadly speaking, to break PD and challenge existing building systems, construction companies should seek innovations to overcome known problems within the industry [15-17].

The manufacturing sector has thrived in part because of standardisation efforts that have been made over the years. The standardisation of processes and product parts has enabled process-oriented companies to succeed in the face of stiff competition [18]. The construction industry has also adopted standardisation of building components since the 1960s, notably in the single-family house-building market in the Nordic countries [19]. This phenomenon has been referred to as industrialised construction', which is defined as a practice resembling manufacturing [20]. While industrialised construction has been reported to have clear benefits [21-23], the uptake of this approach remains low [24,25]. Additionally, no published reports describe a company's successful transition from traditional project-based construction to a process-based approach. The reason might be the fluctuating nature of the construction industry that makes conventional house-building companies unwilling to change an established ad-hoc problem-solving culture, make long-term fixed strategic commitments, and invest in platforms to address risks associated with housing production and supply (e.g., [24,26,27]).

Only a few studies have investigated PD and its effects over time in the construction industry. A notable example is a longitudinal study on the management of a portfolio of business models by [28], which illustrated the importance of continuously evaluating and fine-tuning the business model and integrating it with the company's strategy. Another was reported by Mahapatra and Gustavsson [29], who studied the characteristics of the construction industry and its PD over the past century, and the way this PD has hampered the development of timber building systems. A third was that of Harris and Buzzelli [30], who examined the development of the housing business in North America and Australia between the 1920s and the 1970s. Their analysis discussed notions of 'PD' and 'embeddedness', arguing that technological development trajectories are reinforced by existing technologies and the impact of institutional, cultural, or environmental factors on development paths.

The lack of empirical research on how construction companies evolve over time and overcome PD may be one of several reasons $[24,25,31]$ for the low uptake of industrialised construction; the burden of past decisions may deter companies from pursuing an industrialised way of working.

By applying a contingency theory perspective to a single industrialised house-building (IHB) company, a theory of EO and PD can be synthesised and used to examine and understand the development and evolution of an IHB company. A contingency perspective is justified because the effects of any set of managerial actions will be contingent on both the external environment and internal decision-making, and because there is a contingent relationship between environment, strategy, and performance. Because of these contingencies on internal and external circumstances, there is no universally optimal way to organise a corporation, lead a company, or make decisions about any given course of action [32].

Previous studies [24,25,33-35] have provided a good overview of the adoption of IHB and the associated challenges at the industry level. Therefore, to better understand the barriers to the uptake of IHB practices and ways in which those barriers can be overcome, the objective of the paper is to demonstrate the evolution of a single IHB company over time and give recommendations on overcoming PD. Our paper investigates the influence of $\mathrm{EO}$ on the development of a construction firm that successfully transformed itself from a traditional construction company to an IHB company over 25 years. In this way, we obtain insights into IHB from a strategic management contingency perspective, showing how different EO elements have influenced the company's development. This work also continues the discussion of Pan et al. [24] by highlighting PD as a potential reason for the low uptake of IHB and suggesting EO as a tool to overcome PD.

Based on the findings of our case study, we argue that an entrepreneurial mindset had a significant and beneficial impact on the studied company's evolution and its ability to overcome PD. The paper uses a contingency lens to study the transformation process over time. The inclusion of the temporal aspect made it possible to understand the roles and relative importance of different aspects of EO at different points in the company's evolution. This understanding may help other construction 
companies to acknowledge the process and effort needed to become an industrialised construction company and overcome PD. Our study is related to and provides empirical backing for, the discussion initiated by Mahapatra and Gustavsson [29] when they analysed the introduction of a wooden building system and the subsequent transition from a formative phase to a growth phase.

The paper is structured as follows. First, we establish our theoretical stance on EO and PD to provide a starting point for the empirical case analysis. Then, we describe our research methodology. After that, we describe the case study and discuss its findings. Finally, we present conclusions and outline reasonable future research endeavours.

\section{Background}

\subsection{Entrepreneurial Orientation (EO)}

EO refers to the activities (e.g., processes, practices, and decision-making) that lead to a new entry [36]. It arises from a strategic-choice perspective [37], which proclaims that new-entry opportunities can be successfully exploited [38]. It, therefore, involves a purposeful focus on intermediate processes aimed at creating new ventures. The key elements that characterise an EO include a tendency to act autonomously and a willingness to innovate, take risks, be aggressive toward competitors, and be proactive towards marketplace opportunities [36].

The vision and integration skills of entrepreneurs and managers are essential for the development of dynamic capabilities, but the use of those capabilities depends on two factors: the management's ability to identify opportunities to change existing routines and resource configurations, and the management's willingness and ability to implement the change [39]. Because EO promotes these qualities, an EO can help firms to develop and maintain dynamic capabilities that confer a competitive advantage [40].

Companies can evolve by identifying entrepreneurial opportunities, which may arise as a result of external shocks. Growth opportunities can also be discovered by analysing current product development projects [41]. Companies that are willing to act proactively and innovatively and to take risks will thus have a better base for change and development than companies with less EO [36]. Therefore, companies should engage in strategy-making processes that give them a basis for entrepreneurial decision-making and action [2].

It has been argued that high-performance companies that can cope with rapidly changing competitive environments, shortened product life cycles, and increased globalisation inherently have an EO [42]. Such companies tend to seek and exploit opportunities more rapidly than their competitors and are more willing to accept the business and financial risks associated with brave competitive moves. Following these arguments, there is a growing body of empirical data that strongly suggests a positive relationship between EO and performance [42-44].

\subsection{Indications of Entrepreneurial Orientation in a Company: The Five Key Elements}

Previous research has suggested a set of organisational processes, taking the form of patterns or models, from which strategic decisions evolve [45,46]. Lumpkin and Dess [36] identified five key elements that make a company entrepreneurial: autonomy, innovativeness, risk-taking, proactiveness, and competitive aggressiveness.

The first of these elements, autonomy, refers to "the independent action of an individual or a team in bringing forth an idea or a vision and carrying it through to completion" [36] (p. 140). Broadly, autonomy means the ability and will to be self-directed in the pursuit of opportunities. In an organisational context, it refers to the ability to act without organisational constraints. In a company where the primary decision-maker is the owner/manager, autonomy is an immediate consequence of the rights of ownership [36]. However, the extent to which autonomy is exercised depends on the level of centralisation and the extent of delegation, both of which may depend on the organisation's size. In studies on small companies, researchers have examined the nature and extent of autonomous 
behaviour by investigating how centralised the leadership is and how often managers delegate authority and rely on technical expertise [36]. Miller [47] found that most entrepreneurial companies had the most autonomous leaders. That is, in small, simple firms, high levels of entrepreneurial activity were associated with managers who maintained central authority and acted as the company's knowledge leader by being aware of emerging technologies and markets.

The second key element is proactiveness which refers to the company's ability to identify future market changes, enabling them to gain a first-mover advantage [48,49]. It also refers to how a company relates to market opportunities in the process of new entry. Entrepreneurial companies do this by seizing the initiative and acting opportunistically to "shape the environment," i.e., to influence trends and perhaps even create a demand [36]. Proactive companies are willing to become market leaders and grasp new opportunities. In this context, strategies based on fast reactions enable excellent company performance and make it possible to secure a market leadership advantage [36]. This advantage is strengthened by experience and progression along a learning curve. Proactivity-oriented companies that take risks by conducting series of experiments learn and gain experience that gives them the courage to introduce new business models including new products and services, operating procedures, and management methodologies, making them well-placed to become industry leaders [47]. Companies that acknowledge the importance of advance recognition can take action based on that recognition, including taking proper prospective steps based on predicted opportunities, demand, environment, and possible future revolutions [50]. These points are summarized in a statement by [51] (p. 949) that proactiveness refers to "seeking new opportunities which may or may not be related to the present line of operations, introduction of new products and brands ahead of competition, strategically eliminating operations which are in the mature or declining stages of life".

The third key element of EO is innovativeness, which reflects a company's tendency to engage in and support new ideas, novelty, experimentation, and creative processes that may result in new products, services, or technological processes [36]. Although innovations can vary in their degree of "radicalness" [52], innovativeness represents a willingness to depart from existing technologies or current practices and venture beyond the current state of the art [53]. A company's innovativeness can manifest itself in many ways. Innovativeness spans a continuum ranging from a simple willingness to try a new product line or experiment with a new advertising venue to a passionate commitment to master the latest new products or technological advances [36]. To capture this range of activities, several methods for quantifying innovativeness have been proposed [52,54-56].

The definition of the crucial fourth element of EO, risk, depends on the context in which it is applied. The first set of definitions relates to uncertainty and types of risk that are often discussed in the entrepreneurship literature, such as personal risk, social risk, or psychological risk [57]. As noted by Baird and Thomas [58] (pp. 231-232), these risks are associated with venturing into the unknown, committing a relatively large portion of assets, and borrowing heavily. Conversely, in the financial literature, the risk is used in the context of the risk-return trade-off, where it refers specifically to the probability of a loss or negative outcome [36]. Miller and Friesen [59] (p. 923) adopted this definition when they described the risk as "the degree to which managers are willing to make large and risky resource commitments-i.e., those which have a reasonable chance of costly failures". High leverage due to borrowing and heavy commitment of resources are consistent with this definition of risk-taking. Thus, companies with an EO often show risk-taking behaviour such as taking on substantial debt or making significant resource investments to achieve high returns by seizing opportunities in the marketplace. However, it can be argued that all business endeavours involve some degree of risk so one cannot think in terms of "absolutely no risk". Therefore, it is widely accepted that risk-taking behaviour ranges from actions involving "safe" risks such as depositing money in a bank or restocking shelves to highly risky actions such as investing in unexplored technologies, bringing new products into new markets, or borrowing heavily [36]. However, there is less consensus about how risk should be measured, so many different methods of accounting for and measuring risk have been proposed $[47,51,60]$. 
The final key element of EO, competitive aggressiveness refers to a company's ability to challenge its competitors to achieve entry or improve its position, i.e., to outperform industry rivals in the marketplace [36]. As suggested previously, competitive aggressiveness is characterised by responsiveness. This may take the form of head-to-head confrontation in which the firm enters a market targeted by a competitor. Alternatively, it may be reactive-for example, it could involve lowering prices in response to a competitive challenge [36]. Competitive aggressiveness also reflects a willingness to be unconventional rather than relying on traditional methods of competing. New entrants can also exploit other forms of competitive aggressiveness, such as focusing on competitors' weaknesses [61], focusing on high value-added products while carefully monitoring expenses [62], and adopting unconventional tactics to challenge industry leaders [63]. In the spirit of Porter [64], three strategies are recommended for aggressively pursuing existing companies: "doing things differently," that is, reconfiguration; changing the context, that is, redefining the product or service and its market channels or scope, and outspending the industry leader. Accordingly, competitive aggressiveness, which refers to a company's responsiveness directed toward achieving competitive advantage, is an essential component of an EO [36].

\subsection{Path Dependency (PD)}

To understand how companies develop over time and how resources are expanded or altered to address changes, it is necessary to examine how companies' past actions may have influenced their current position and prospects [65]. PD refers to the idea that past events and decisions influence current decisions and future ways of working [66,67]. Historical decisions and events can magnify the primary advantages of an innovation over time due to 'learning by doing and using' $[4,6]$, network externalities [10,68], institutional persistence [9,69], and sunk investments [70]. Early works by Arthur $[4,5]$ and David [6] used PD to explain processes of technology adoption and industry evolution. They argued that past decisions lock organisations into pathways that constrain future choices and the ability to respond to changes. Therefore, once a technological change in some direction is initiated, it becomes increasingly difficult to change its course [71]. Most market actors prefer to develop further or use existing technology. Therefore, PD stabilises the existing innovation systems [29].

The constraints can be seen as an accumulation of inertia, which can have either negative or positive effects on the company: past actions usually prevent a company from evolving in the desired direction, but they may also provide a competitive advantage by supporting the company's development. For example, Mahapatra and Gustavsson [29] and Franzini et al. [31] identified possible barriers to the adoption of wooden multi-storey construction, one of which was described as a path-dependent construction regime. Strong PD is also reflected in the strong position of traditional concrete builders in the construction industry $[29,72,73]$ and the industry's limited experience with collaborative networks and multi-actor construction projects, both of which are significant barriers to efforts to increase the market share of wooden multi-storey construction [74,75].

Patchell [76] studied PD in the Japanese house-building industry, focusing on interactions between customers and manufacturers. He found that large house-building companies operating at the national level are constrained by PD in different ways to those affecting smaller companies operating at a local or regional level. Large house-building companies have sought growth through substantial investment in economies of scale and scope, which has necessitated geographical expansion accompanied by a loss of local responsiveness. Conversely, companies operating at the local or regional levels are constrained by local traditions and their reliance on local workforces, materials, and relationships. This confers some competitive advantages but reduces the longitudinal scope of their activities. Patchell [76] argues that the local embeddedness of smaller house builders has compelled national companies to address the challenge of creating a sales-and-distribution infrastructure that can interact with customers locally.

In sum, the historical background of a company or industry may either support or hinder its efforts to change. The theory of PD assumes that decisions are initially open to revision and impose few constraints on subsequent development, but become increasingly fixed over time and thus impose 
increasingly severe constraints on present and future choices [66]. Therefore, past decisions may dictate a firm's current and future actions. Additionally, Teece [77] argued that events in an organisation's history would constrain and affect its future behaviour to some degree. PD thus develops over time as the configuration and understanding of 'automatic' processes and capabilities become embedded in what the company does and how it does it. Learning and behavioural theories of organisational change recognise that decisions to change are dependent on the willingness to change, the awareness of the need to change, and the perceived capacity to change effectively [27,78], all of which may be reduced by such embedding of processes and practices.

\section{Research Methodology}

\subsection{A Longitudinal Case Study}

Research on organisational paths requires a longitudinal perspective and analysis of datasets such as chronologies or time series (simple or complex) that provide information on sequences of events in an organisation's history and the actions it has taken [79]. It is only by considering temporal data that we can identify and explain the fundamental mechanism(s) governing the construction of organisational paths. Consequently, PD research is always process research [80,81]. Additionally, if we want to understand how and why strategic systems become constrained or unable to respond to environmental changes, a qualitative approach is most appropriate. Furthermore, because of the need for a process perspective and the objective of grasping the inner logic of strategic reasoning, an interpretative approach is essential. What is needed is a sort of "thick description" [82] of the field's development, generated by gathering qualitative information on how and why strategic decisions were taken or not taken, and how they are explained (or not explained) by the actors in the field. A case study approach was considered most appropriate for this purpose because it would enable us to identify complex causal relations and situate them in specific contexts [83].

This work focuses on a single case [79], which can be considered appropriate based on Siggelkow's [84] precepts for convincing case studies. First, the novelty of the case is apparent; the studied company has a reputation as a successful forerunner in house building using industrial manufacturing techniques. Second, the company has moved most of its production into a factory milieu, which is unusual for companies in its sector. Third, the potential for new insight is high because the analysis should reveal endogenous and theoretical traits, illuminating company characteristics that might otherwise remain unseen.

The case company is family-owned and manufactures industrially-built multi-storey modular timber buildings in Sweden using a unique 'volume construction' technology. The company is considered successful because it has existed for over 90 years and has transformed itself into an industrialised company in recent decades. Equally important was the fact that the company has maintained detailed records throughout the transformation, making it an excellent source of data for this type of study. Besides, the authors have good connections to the company, which made it possible for us to conduct in-depth interviews with relevant employees.

The unit of analysis is the interaction between developments in the external housing market, the EO activities of the case company's managers, and the application of the company's external resources between the years 1993 and 2018. The study is based on data for the years since 2000 . However, the story begins in 1993 because that was the year in which the company began the industrial production of multi-storey timber buildings from modules. The availability of relevant data spanning an interaction period of 20 years made it possible to conduct a longitudinal case study.

The case study is retrospective in the sense that it is based on historical archival data, but the information recorded in the archives was collected in real-time. The events and activities under investigation have already occurred, and their outcomes are known. The timeline of events and the variables that changed over the period were reconstructed after the events had occurred [85]. However, 
to compensate for the uncertainty introduced by using retrospective data (which may arise from factors such as the recall effect), we crosschecked the interviews and the archival data for consistency.

\subsection{Data Collection and Analysis Methods}

The primary data collection method was in-depth, semi-structured interviews. Eight people were interviewed, five of whom had worked for the company for over 30 years. Two interviewees had collaborated intensively with the case company over the last twenty years when guiding students in writing academic articles and reports on the company's operations. The interviews were conducted between April 2017 and September 2018. Table 1 summarises the interviewees' roles and the nature of the information they provided. To enable the interviewees to present their narratives, the interviews began with openly formulated questions (see Appendix A) and continued with more detailed questions about the company's history. All the interviewees gave their informed consent orally for inclusion before they participated in the study. The study was conducted following regulation (EU) 2016/679 of the European Parliament and the Council. These provisions are often referred to as the General Data Protection Regulation (GDPR). The following ethical procedure was followed; all the interviewees were before the interview given written informed of the research agenda and publishing strategy, who was doing it, and were asked to give permission to record and go forward with the interviews. Next, the interviewees crosschecked and verified the transcripts. The case company's chief executive officer (CEO) approved the final manuscript.

Table 1. Interview data.

\begin{tabular}{|c|c|c|}
\hline Date & Role of the Interviewee & Scope and Target \\
\hline 10 April 2017 & Production manager & To understand the company's production operations \\
\hline 17 April 2017 & Project developer & To understand the company's production operations \\
\hline 11 June 2018 & $\begin{array}{l}\text { Chief executive officer (CEO) of a } \\
\text { subsidiary company }\end{array}$ & $\begin{array}{l}\text { To understand how the company works with its } \\
\text { collaboration partners }\end{array}$ \\
\hline 12 June 2018 & CEO & To understand the history of the company from 1993 to 2018 \\
\hline 18 June 2018 & $\begin{array}{l}\text { The professor who has collaborated } \\
\text { previously with the company }\end{array}$ & $\begin{array}{l}\text { To understand the role of the university's research activities } \\
\text { on the company's focus areas }\end{array}$ \\
\hline 19 June 2018 & $\begin{array}{l}\text { The professor who has collaborated } \\
\text { previously with the company }\end{array}$ & $\begin{array}{l}\text { To understand the role of the university's research activities } \\
\text { on the company's focus areas }\end{array}$ \\
\hline 20 June 2018 & CEO of a subsidiary company & $\begin{array}{l}\text { To verify the path dependency (PD) of the activities in the } \\
\text { timeline between } 1993 \text { and } 2018\end{array}$ \\
\hline 26 September 2018 & $\begin{array}{l}\text { A manager of a company that transfers the } \\
\text { case company's technology abroad }\end{array}$ & $\begin{array}{l}\text { To understand the plans of the company regarding } \\
\text { technology transfer abroad }\end{array}$ \\
\hline
\end{tabular}

As noted by Guest et al. [86], saturation may be achieved after only six interviews. As with all aspects of qualitative research, the depth of the data is often more important than the numbers [87]. Interviewees were chosen based on their expected ability to provide substantial insight into the company's history, the context of its construction and marketing activities, and its production operations. Another criterion for selecting interviewees was that the persons had been active in the firm during its transition to an IHB company. These criteria used to select interviewees were strictly followed to recruit a group of interviewees who could provide a broad overview of the company's operations, managerial activities, mindset and, market changes during the studied period. The selection criteria made the number of interviewees relatively small. However, the targeted selection ensured that each interviewee could speak with authority about the organisation's managerial activities. The interviewees had witnessed first-hand the changes in the organisation from a position that allowed them to understand the decisions that lay behind the company's evolution. Although the group of interviewees was small, their collective expertise and extensive involvement in the company meant their responses gave an adequate description of the changes that occurred in the organisation. According to Romney et al. [88], 
a small number of participants is justified in cases where the participants possess high expertise on the issue being studied.

The interviews were conducted in pairs, as suggested by Lundahl and Skärvad [89]. The benefit of having two researchers participating in interviews is that while one researcher conducts the interview, the other can observe, make notes, and ask follow-up questions. To minimize the impact of researcher bias, all interviews were conducted by the researcher who had the least personal contact with the company. To increase reliability and validity, the interviews were recorded and transcribed, and the transcripts were crosschecked with the interviewees. An inductive approach was used to analyse the responses because the data required in-depth reading and rereading to ensure validity and avoid bias when coding. The inductive approach made it possible to identify key themes in the area of interest by reducing the material to a set of categories.

The archival timeline was used to find evidence of the five characteristics of entrepreneurial companies proposed by Lumpkin and Dess [36]. Independent actions were taken as evidence of autonomy. First-mover advantage and efforts to create demand, new opportunities, or new business models were taken as evidence of proactiveness. Departing from established technologies or practices and venturing beyond state of the art were taken as evidence of innovativeness. Venturing into the unknown, committing a relatively large proportion of the firm's assets, and heavily borrowing were taken as evidence of risk-taking. Finally, focusing on competitors' weaknesses, seeking high value-added products, and adopting unconventional tactics to challenge industry leaders were taken as evidence of competitive aggressiveness. Interviews were used to support the findings, better understand how the world looked when the studied actions and decisions were taken, and develop an understanding of the company's managerial activities over the 20 years.

To analyse the link between the external market environment and managerial activities, the process data were organized into a timeline (see Appendix B) consisting of three layers: the external market environment, the company's managerial activities, and the use of external resources such as academic collaborations and consultants. This is consistent with the contingency perspective adopted in this work. The timeline gave us a visual representation of the activities that occurred between 1993 and 2018 and illustrates the interplay between developments in the housing market, the company's development, and its academic collaborations. The timeline was based on secondary archival data including five academic theses [90-94] published between the years 2000 and 2013, a company history report [95], and public reports of the company's sales and collaboration agreements. These documents provided process data on the company's history [81] and can be considered to strengthen the study's internal and construct validity. Importantly, the information they provide can be assumed to be reliable. The university interviewed professors supervised the dissertations and oversaw the writing of the research reports. The research reported in these dissertations is also presented in peer-reviewed articles [18,96-100] and all of them include a temporal aspect because the result, analysis and contributions cover, each, roughly a five-year period. The research-based data used to inform the narrative was based on these dissertations and stems from a meta-analysis centered on the scientific and company rationale addressed and results presented in these dissertations. The timeline was validated by two managers who had worked for the company during this period and by two university professors who had studied the company during this period. This validation process can be seen as a form of triangulation that enhanced the validity of the research (e.g., [79]). Denzin [101] argues that triangulation in research is essential when seeking to find evidence for, explain, predict, or understand specific empirical phenomena. Triangulation is also commonly used to eliminate threats to a case study's validity (e.g., $[79,101])$.

\section{Results}

Here we discuss the main events that occurred between the years 1993 and 2018 in terms of the company's managerial activities, external market changes, and external resource utilisation. We aim to 
identify the managerial actions that contributed significantly to the company's transformation into an industrialised construction company and how external activities affected the transformation.

\subsection{Surviving the Housing Market Crisis: Towards Industrialised Construction (1994-2004)}

In the 1990s, Sweden's house-building market suffered a crisis. Many small and medium-sized companies disappeared or were purchased by larger Swedish companies, as noted by one of the company's project developers:

"In the 1990s, all these medium-sized companies disappeared ... They were bought, merged with larger companies, or went bankrupt."

The case company was in the same situation as other smaller and local construction companies, as noted by one of its managers:

"The building crisis was pushing the company towards bankruptcy ... the market was going downwards quite steeply, and we had to do something."

The company was close to shutting down. The project developer explains that at that time, the company operated in a similar way to other construction companies.

"We were a traditional builder, built everything. So we went from over 100 employees to 20 employees in a very short time."

In 1993, the company made a brave decision to change its focus and start building houses at a reasonable price using industrialised technology, as a manager explains:

"So we moved the building sites inside the factory environment and put the labour hours primarily in the factory so we could keep our staff in the neighbourhood."

The decision to move towards industrialised construction was partly driven by a critical regulatory change in 1994 that permitted the construction of multi-storey timber buildings and, thus, provided a new business opportunity. Multi-storey timber buildings had previously been prohibited because of the risk of city fires. Two Swedish cities suffered significant human and financial losses due to city fires in the 19th century. A university professor explains the change in regulations:

"We adopted the Euro codes, which made it possible to build wooden structures of more than two storeys."

As a result, instead of closing down, the company saw an opportunity to relaunch its production with an existing plant. Therefore, it began searching for new industrialised techniques for multi-storey timber house building.

Industrialised construction required a new way of thinking and producing houses. A new type of 'volume building' technology was developed in collaboration with a local, technical university. As a result of this public-private collaboration relationship, a new product was launched in the housing market. The company produced its first products in the University City to prove the concept's feasibility and to demonstrate the product's quality and the viability of the production method. Convincing the market in this way was necessary because the public perception of industrialised construction was poor, as the product developer explains:

"The production process was simply too unknown. However, we also realised that the market would recover in metropolitan areas, particularly in the university cities."

Over the next 10 years, the company had to solve many technical issues with the production platform, and the university tested and verified several solutions to these issues. The company also had some luck because the Swedish government decided in 1997 to provide financial support for the development of prefabricated timber components. The public-private relationship started in the early 
1990s and was mutually beneficial: it enabled the company to verify the feasibility of its production methods while allowing the university's staff to research a real-world setting. A manager from the company describes the public-private relationship as very important in terms of building market confidence in IHB because the market was unconvinced by the case for industrially built houses in the early 2000s.

"I will say the university played an important role as a confidence builder for us. To a large extent, cooperation became a market requirement for our development."

\subsection{From Technology and Product Orientation to Process Orientation (2004-2018)}

Before 2005, the company had to focus on convincing the market that its product was viable and safe. Once the product's credibility had been established, the company felt that it could start competing on an equal footing with other construction companies. Therefore, its focus shifted from product and technology orientation to process orientation, as explained by a university professor:

"So until about 2005 the attitude was almost 'technology will fix everything', but afterwards more process-based long-term thinking started becoming more prevalent."

In practice, process-orientation meant that the company began to develop more long-term collaborative relationships with architects and customers. The architects needed to be involved early in the design phase to ensure they understood the technical platform's capabilities and limitations. The production system could produce certain types of housing efficiently, but there were other designs for which it was unsuitable or uneconomic. The production process thus required the customer to be involved from an early stage to ensure that the production methods could meet their requirements. This insight the company acquired was based on Björnfot's [91] work from following the case company from 2002. The study showed that the company had possibilities to overcome the limitations related to customer flexibility while maintaining a relationship with suppliers. The main finding was that long-term contracting and complementary resources, e.g., architectural capacity, sub-contractors and consultants should be introduced into the company, to acquire critical resources. Earlier studies by Bergström [90] showed that the company had communication and cooperation difficulties with different actors, which led to recognition of the need to build a strong relationship with key stakeholders.

At the beginning of the year 2000, construction firms started adopting a lean philosophy; the case company began incorporating lean practices into its technology platform from 2002. At first, the company introduced continuous improvement, standardised work, maintenance of equipment and tools, and responses to defects. Continuing on Meiling's [93] studies on continuous improvements, the platform evolved over time to include both standardised components and standardised processes. Later, Jansson [94] demonstrated how a platform consisting of standardised components and standardised processes could be systemised and developed over time. Other lean practices such as daily huddles, scheduling, work floor layout, and visual information were introduced later, much from the insights of Höök's [92] studies, where she showed that lack of standardised work, top-management strategies, and employee loyalty, hindered the company from approaching a lean culture. These lean practices were subsequently adopted throughout the organisation with the help of an external consulting company, as a manager explains:

"We wouldn't be able to do this [build with industrialised methods] if the organisation wasn't lean. And this journey is about taking small steps into the future, and you asked how we do the ordinary day-to-day operative work. So we use these principles everywhere in the organisation."

A company manager stated that the reason for the company's success is that it adheres to a lean philosophy in all its management practices:

"It [lean] is not complicated, but it is very powerful, so when I do management things, I follow it every day. One goal that has emerged from our processes is that we are aiming to be the leading lean company in the country by 2022." 
Around 2014, the company realised that its production capacity needed to be expanded, so it built a new factory based on lean principles that started production in early 2018. The recent investment in this new production facility exemplifies the company's mindset and demonstrates the long-term social work it has done to secure the wellbeing of the local community. The manager agrees that there is local pride in the fact that the factory was built in the hometown. The company also considers it essential that the hometown managed to provide the best conditions for the factory despite competition from other locations. The factory provides jobs for the local community and is a source of local pride, so the company's managers feel that they have a social responsibility. The manager explained:

"Those in the company's third, fourth, and fifth generations see a heritage we want to preserve. We come from a quite small neighbourhood, a rather small area, and when you make a promise to those who are engaged with the company and its progress, you want to keep it."

Since its founding, the company has worked closely with the local community. As a result, it has been seen as an attractive employer and has enjoyed good relationships with residents. The collaboration has enabled the recruitment of new employees when the company has expanded. The question they ask when recruiting is not what the employees can do for the company, but what the company can do for the employees, as explained by the manager:

"We talk about the reasons for someone to start working here and why they should invest their time in our company. If you create a bad reputation, it will come back. You need to think long-term."

The company is currently the market leader in Sweden and plays a crucial role in the country's housing market. It has also attracted international interest and found a market in a neighbouring country-Finland. The company has, therefore, decided to sell its knowledge and expertise in industrialised construction abroad, as a manager explains:

"The reason for that is that we need this project abroad in order to benchmark ourselves and our ability to sell technology transfer-how to sell our knowledge. So we have an agreement with this foreign company that is buying our knowledge."

\subsection{Innovative and Collaborative Entrepreneurs}

The company has always been family-owned, the current owners of the company being the fourth generation in the company's history. Its founders were building contractors, whereas many of its competitors have backgrounds in forestry and the timber industry, as a manager explains:

"We were building contractors from the beginning. We are entrepreneurs. We were not brought up in the forest industry. Many other industrialised timber builders have their roots in forestry. We come from the other part, which is more focused on selling and products."

The company has a long history of innovation and strategic thinking, as explained by a manager:

"The company's owners prioritise long-term thinking. You need to bear that in mind to understand the reasons and background for making certain decisions. An urge to invent things, solve problems, and innovate has been an important aspect of the owners' values for many years, as a way of coping with the rise and fall of the market, and making the best of things. It's also important that they have the desire and courage to try new things."

The public-private relationship has now lasted over 25 years. It initially focused mainly on testing technical solutions, but more recent collaboration has focused mainly on understanding the company's implementation of lean principles [92]. One factor that has contributed to the relationship's success is the active involvement of the company's managers, as discussed by a professor at the university:

"This has succeeded because the company's management has been involved in all of the research." 
The company differs from traditional construction firms both in terms of its process orientation and because of its understanding of the value of implementing new ideas. As the university professor put it:

"You can do research and development, but you also need to implement the innovations. Otherwise, the benefits will be lost."

The company works closely with other industries to learn from the best about the implementation of lean working practices. The company reciprocates by allowing other companies to visit their factories to understand lean in practice. The company is not afraid of other companies' attempts to copy its lean practices because it is difficult for other companies to copy a specific lean way of working; each company must develop its way of working that suits its particular environment. A company manager explains it in the following way:

"I always invite our competitors to come and look at the factory or our organisation. I talk about it without showing our figures, but I do show our strategies and explain how we do things. They can pick up on some things but they can't do the whole thing. Therefore, we are always a step ahead. And if they manage to fix something, we will already have moved six months ahead, making what they learned history; by that point, we will have a new way of working."

\section{Discussion}

\subsection{Overcoming Path Dependency through an Entrepreneurial Mindset}

In the early stages of the company's transition to IHB, it had to develop its technology platform to produce quality products in a factory setting efficiently. The quality of the product was crucial to convincing future customers about the merits of this new way of building houses. At that time, the company's main focus was on the technology platform and product. However, as the platform matured to the point of needing only specific small fixes, the company's attention shifted towards the customers' needs. The company, therefore, began developing long-term collaborative relationships with customers to understand customer needs thoroughly. It emerged that the customer needed to be involved early in the production process to ensure that the production methods could meet their requirements. The effects of industry PD and the influence of existing building systems were both readily apparent, for example in this statement made by a manager: "We got an inquiry at the beginning of the year 2000 about building almost 200 temporary student apartments. However, we never made an offer because industrialised construction was associated with modular building, which had a bad reputation. We did not want to denigrate our product". To overcome this, the company used internal and external resources to convince the market that IHB constitutes a better way of working.

The company has also been keen on being sensitive to customer needs, and the public-private relationship has helped it to meet those needs. Both parties benefited from the collaboration: the company gained access to research knowledge and a skilled workforce in the form of $\mathrm{PhD}$ and masters' students, while the university could use the company as a case to study an industrialised way of working and industrial projects. As shown earlier, the company has matured through research by Bergström [90], Björnfot [91], Höök [92], Meiling [93] and Jansson [94], providing key insights on how to overcome hindrances common to the construction business.

Through the public-private relationship, the company received help with creating and testing new technologies related to its product platform, thereby gaining legitimacy in the market (as discussed earlier), while the academics could test their theories in practice and gain legitimacy in academia. These mutual benefits were clearly illustrated by the CEO when he explained how the company managed to penetrate the market by using the university's work to validate their product and prove its safety, addressing customers' concerns. This collaboration was necessary because most property owners interested in building houses only had experience with concrete construction. 
Teece [77] argued that events in a company's history affect its future behaviour. The case company decided to invest in its technology platform and change its business model at the beginning of the 1990s. As a result, it changed its element production to volume production, producing 2- to 6-storey houses. This decision did indeed constrain the company in a way since its platform solution did not initially meet its customers' needs. The company, therefore, began working closely with architects and customers by involving them earlier in the "construction process" to overcome this challenge. The company also lobbied and promoted its products, and used a proof-of-concept pilot project to prove the viability of its product to customers and the broader market. The success of these efforts reveals some potentially general ways of overcoming a strong PD in an industry.

Another illustration of PD is the way the early decision to move to volume production influenced the company's strategic work. This decision gave the company boundaries that gave rise to a clear focus and goals. Because it invested in building a factory and moved labour hours into the factory, the company was obliged to either keep up production at the factory or fail to recoup its investment. In other words, past decisions locked the organisation into pathways that constrained its future choices and ability to respond to change.

The company's primary manufacturing operations and $30 \%$ of its project engagement take place at the local and regional levels. Surprisingly, these statistics are similar to those for many large companies that invest heavily to benefit from economies of scale [76]. Importantly, the case company has not had to sacrifice local responsiveness to achieve this. Patchell [76] argues that PD explains how both large national and local housebuilders, are constrained in their operations. However, our study suggests that a "local" company can overcome the constraints imposed by PD.

Mahapatra and Gustavsson [29] discussed conditions that may support a transition of a wooden building construction system from a formative phase to a growth phase. We have shown that many of their initial thoughts can be verified. Next, five conclusions from their study will be discussed.

First, they propose that the education of professionals about timber construction, in particular, consultants, engineers and architects, as well as policy and decision-makers, and the general public would expand the knowledge platform for timber buildings. In accordance with this claim, the results presented here show that the case company did indeed work closely with many professionals to develop an understanding of IHB. Second, the authors proposed that educational and training programmes in higher learning centres (e.g., universities) oriented towards wood-based industrialised building would further expand this base through the continued supply of the workforce. Accordingly, the public-private relationship allowed access to knowledge and a skilled workforce. Third, they suggested that encouragement for new firms to enter the timber construction system would help increase the number of actors in the emerging innovation system. While this may be true, the results of this study demonstrate that one cannot simply enter a market; successful entry requires long-term commitment and EO. Also, because the case company is an industry leader, their actions may seem like a source of PD to others seeking to enter the IHB market. Fourth, they argue that the facility to the existing firms to move beyond the stage of small-scale experiments would be beneficial. Particularly interesting are those medium-sized firms that produce prefabricated timber single-family houses. Again, such companies have a history and would probably find it challenging to overcome their industry's PD without EO, long-term thinking, and active external collaboration. Finally, they suggest that coordinated and collaborated efforts will contribute to unify the relatively fragmented wood industry. Collaboration is needed between different sectors and levels, especially between industry, authorities, researchers, construction experts and their networks. The results presented here show that PD can be overcome, by focusing on a niche market segment, developing a platform in collaboration with external actors (e.g., architects, universities and stakeholders) and addressing customers' concerns, but the results do not show how this can unify a fragmented industry. 


\subsection{Building Path Dependency, Strengthening Market Position}

Although the case company's objective was to overcome industry PD and develop affordable housing, it may have inadvertently made it harder for other wood-based construction companies to enter the market by creating new PD. It took over a decade for the company to achieve acceptance in the market, which was done by active lobbying and collaboration with relevant professionals [88]. Many property developers and construction companies have since become familiar with the case company's products and construction methods, to the point that (as one manager put it) their way of working has become the norm in modular construction. As a result, modular construction in Sweden has been placed on the pathway developed by the case company; that is to say, their actions and success have contributed to the creation of new path dependencies. Many current industry regulations have emerged as a result of the journey the company has made. The same is true for the image that professionals and customers have when discussing modular construction. Therefore, the case company's actions have made it harder for new competitors to enter the market. Even if new companies try to enter the market by copying the case company's products and methods, PD will probably hinder their efforts.

\subsection{Entrepreneurial Orientation and Long-Term Collaborative Relationships}

The contribution of an EO to the case company's success can be evaluated by considering the extent to which it has displayed the five key components proposed by Lumpkin and Dess [36]: autonomy, innovation, degree of risk-taking, proactiveness and competitive aggressiveness.

The company has shown autonomy by independently acting when faced with harsh competition and market turbulence. By completely changing its business model from project-based to process-based building and challenging traditional construction companies, the case company proved itself to be remarkably innovative. However, this innovative action was only possible because of the company's appetite for risk-taking, revealing another facet of its EO. The company took a big risk by changing its way of working and moving its production into a factory: in addition to departing from existing technologies and current practices, it sought to bring a new product to market while investing heavily in production facilities and technology. Its managers thus demonstrated a strong EO and remarkable leadership. The company also displayed proactiveness by being the first to bring wooden modular buildings to the market. It thereby gained the first-mover advantage, as discussed by Lieberman and Montgomery [48]. This forced its managers to rethink their business model to create demand because customers were unfamiliar with products of the type they were offering. By lobbying for the product as they did for the first 10 years (through the public-private relationship) they created demand and new opportunities both for themselves and for their customers and the broader industry. The introduction of their product allowed customers to acquire high-quality turnkey wood-based modules that can be assembled on site much more quickly than a traditional building project can be completed. A key advantage is that the product can be assembled quickly and does not need the drying time associated with concrete-based projects. Therefore, the customer can sell and/or rent apartments much more quickly, allowing them to obtain revenue earlier than would otherwise have been possible. In this way, the company demonstrated competitive aggressiveness: they identified a common problem of traditional construction companies (the long drying time of traditional concrete buildings) and used it to argue strongly for the added value of their product, adopting unconventional tactics to challenge industry leaders. As noted above, the case company's way of building houses is much faster than the traditional approach, bringing more value to the customer more quickly.

\subsection{Guidance to Overcome Path Dependency in the Construction Context}

As presented in this article, overcoming PD takes a long time, and companies must deal with many obstacles in order to establish themselves in the market. Here we present some general guidance for other companies to overcome PD issues and incorporate innovation. First, due to inherent PD in the construction industry, companies should be proactive and establish a long-term relationship 
with different stakeholders. The idea is to challenge the preconceptions decision-making bodies have (e.g., architects, state planners, investors) and establish collaboration in an early stage. This collaborative work enables companies to overcome PD. It also nurtures and spread innovation between companies and different decision-making bodies. Second, promotion of own brand (use proof-of-concept pilot project to prove the viability of its product to customers and the wider market) and use highly respected partners to promote the product, create demand and new opportunities both for the company and for their customers. Third, find and focus on a niche market segment. In so doing, the company can develop the product for this specific market and focus on customers' needs, instead of battling on many fronts in the whole market. Fourth, a niche market focus supports working with standardisation of products, processes, components. The adoption of lean philosophy is a way for companies to structure their operations around standardisation. Hence, the use of consultants may accelerate the development toward a more lean company. This rational way of working may attract established stakeholders used to working in a certain way. Fifth and finally, top management is expected to make long-term fixed strategic commitments, and invest in platforms to address risks associated with housing production and supply; thereby companies can gain a competitive edge over its competitors.

\section{Conclusions}

This paper reports a longitudinal case study of a traditional construction company that was able to transform into a successful IHB company in 25 years. We chose a longitudinal approach to examine PD and EO which in our view is appropriate as the focus is to reveal key events in the company's history to obtain a further understanding of how a project-based construction company has evolved into a process-based market leader. This paper has contributed to the literature and theoretical buildup of PD, EO and strategic orientation of IHB companies by retrospectively investigating how an IHB company has evolved and overcome construction PD with EO over time. Additionally, we have provided a guide for how construction companies can overcome PD. The results showed that PD could be overcome, by focusing on a niche market segment, developing a platform in collaboration with external actors (e.g., architects, universities and stakeholders) and addressing customers' concerns. The findings of our case study also show that collaboration with other organisations and the EO of the company's managers have also enabled the company to overcome its PD and change the company's focus over the years, in response to external changes and market needs. Thus, this paper also contributes to the field of EO by showing that an entrepreneurial mindset can be a key to success when applying a process-based business approach in construction.

The strength of this case study comes from its ability to story-tell and explain how EO enabled the company to succeed despite its PD. However, no study can answer all required questions, and future research endeavours should focus on understanding more deeply how PD encourages or discourages construction companies' development towards industrialised construction, and whether an entrepreneurial mindset and a willingness to collaborate could be taught to managers in order to overcome or reduce the influence of PD. The generalizability of the results is also limited, not only for the qualitative nature of the study but also because a single case company and its history have been studied without any more in-depth investigations of other construction companies during this same period.

Author Contributions: Conceptualization, P.U. and R.L.; Methodology, P.U and R.L.; Validation, P.U. and R.L.; Formal Analysis, P.U and R.L.; Investigation, P.U and R.L.; Data Curation, P.U and R.L.; Writing-Original Draft Preparation, P.U.; Writing-Review \& Editing, P.U and R.L.; Visualization, P.U.; Supervision, P.U and R.L.; Project Administration, P.U and R.L. All authors have read and agreed to the published version of the manuscript.

Funding: The research was conducted as part of the Aalto University's research project “Building 2030-industrialised construction" which is funded by 16 companies from the construction sector. The research has been financed by Aalto University's Digital Disruption of Industry (DDI)-project funded by the Strategic Research Council of the Academy of Finland. The Finnish Science Foundation for Economics and Technology has also financed the research. 
Acknowledgments: The authors thank Luleå University of Technology and the Department of Construction Management and Building Technology for their support.

Conflicts of Interest: The authors declare no conflict of interest. The funders had no role in the design of the study; in the collection, analyses, or interpretation of data; in the writing of the manuscript; or in the decision to publish the results.

\section{Appendix A}

Interview themes and questions (questions were posed either in Swedish or Finnish). Different questions were posed for different interviewees depending on their background. Before the interview permission to record, used and publish the data were asked, and that the study follows General Data Protection Regulation (GDPR).

- $\quad$ Background

$\bigcirc \quad$ Tell us about your background.

○ Describe the most critical points for the company since the 1990s until today (2018). (aiming to depict the important time points for the company)

$\checkmark \quad$ What should we especially understand in this context?

- Market and customer orientation

$\bigcirc \quad$ Can you reflect on the market? Has the focus all the time been in low-cost?

$\bigcirc \quad$ Where do you think your company's long-term thinking comes from?

$\bigcirc \quad$ Where does your focus on customers come from (not traditional thing in construction)?

$\bigcirc \quad$ Describe your way of doing business. Has it changed the Swedish construction business or have you seen any change?

$\bigcirc \quad$ How have you influenced this market?

- Internal decision-making processes

How you make decisions in the company?

Who is looking into the future and who makes the daily decisions?

- Technical platform

$\quad$ When was the platform ready?

$\bigcirc \quad$ How was it developed and by whom?

- External collaboration

What kind of role has the university played?

$\bigcirc \quad$ What kind of plan have you had with the university?

$\bigcirc \quad$ How are you collaborating with consultants?

- Lean philosophy

Where does that ideology come from?

How are you practising lean?

What has been the role of Lean in your work?

- Platform (technology) transfer

When did the idea of technology transfer come into being?

What has happened so far and by whom? 
What else is going on?

How long does the transfer process take?

What have been considered important for the success of the transfer and why?

What challenges have you encountered so far and why?

What successes have you experienced so far and why?

How do you prepare for technology transfer? (Contracts, IPR rights, etc.)

What concrete things are being transferred between the companies? (Physical devices, people, etc.)

What kind of know-how needs to be transferred between companies?

How will know-how be transferred?

How will communication continue after the technology transfer?

- Other

Is there anything else we should have asked but would have liked to say?

Who should we interview? 


\section{Appendix B}

The interplay between the developments in the housing market, the company's development, and university collaboration.

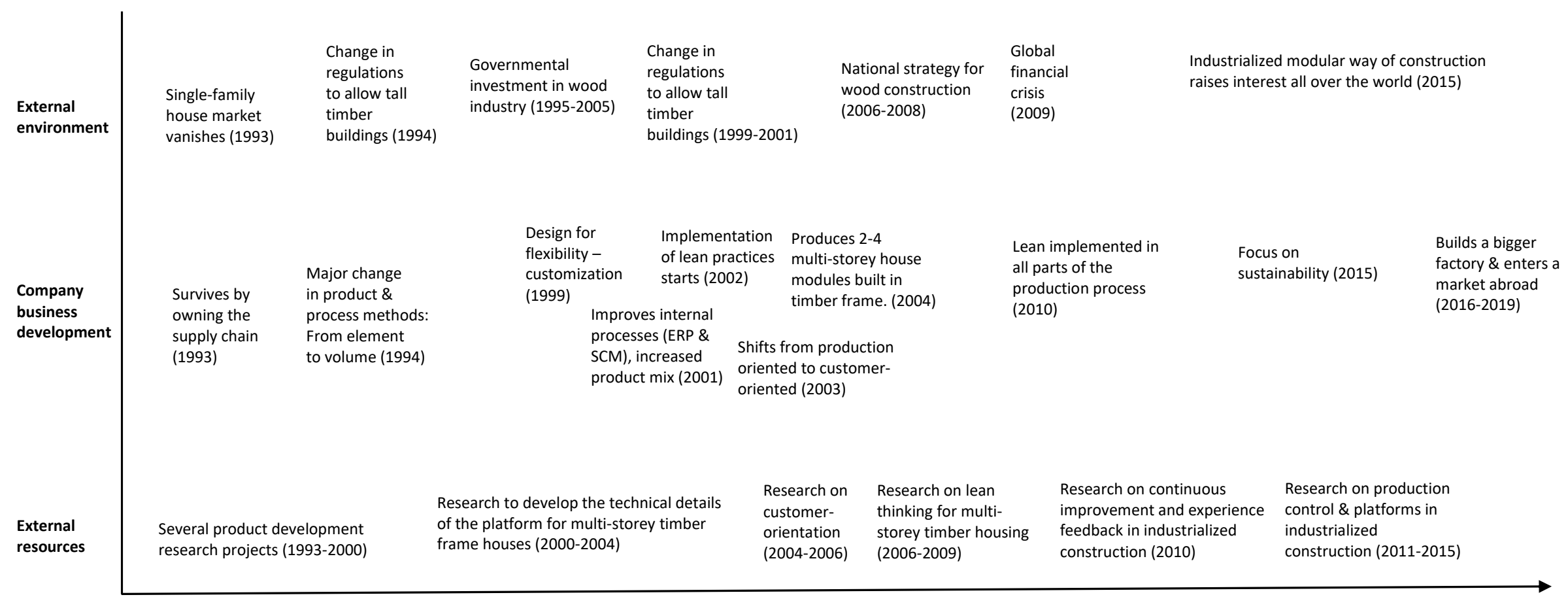




\section{References}

1. Ferreira, J.; Azevedo, S.G. Entrepreneurial orientation (EO) and growth of firms: Key lessons for managers and business professionals. Probl. Perspect. Manag. 2008, 6, 82-88.

2. Rauch, A.; Wiklund, J.; Lumpkin, G.T.; Frese, M. Entrepreneurial orientation and business performance: An assessment of past research and suggestions for the future. Entrep. Theory Pract. 2009, 33, 761-787. [CrossRef]

3. Martens, C.D.P.; Machado, F.J.; Martens, M.L.; de Freitas, H.M.R. Linking entrepreneurial orientation to project success. Int. J. Proj. Manag. 2018, 36, 255-266. [CrossRef]

4. Arthur, W.B. Competing technologies, increasing returns, and lock-in by historical events. Econ. J. 1989, 99, 116-131. [CrossRef]

5. Arthur, W.B. Increasing Returns and Path Dependence in the Economy; University of Michigan Press: Ann Arbor, MI, USA, 1994. [CrossRef]

6. David, P.A. Clio and the economics of QWERTY. Am. Econ. Rev. 1985, 75, 332-337.

7. Gann, D.M. Innovation in the construction sector. In The Handbook of Industrial Innovation; Dodgson, M., Rothwell, R., Eds.; Edward Elgar Publishing: Cheltenham, UK, 1995; pp. 202-212. [CrossRef]

8. Grübler, A.; Nakićenović, N.; Victor, D.G. Dynamics of energy technologies and global change. Energy Policy 1999, 27, 247-280. [CrossRef]

9. Pierson, P. Increasing returns, path dependence, and the study of politics. Am. Political Sci. Rev. 2000, 94, 251-267. [CrossRef]

10. Nelson, R.R. An Evolutionary Theory of Economic Change; Harvard University Press: Cambridge, MA, USA, 2009.

11. Reichstein, T.; Salter, A.J.; Gann, D.M. Last among equals: A comparison of innovation in construction, services and manufacturing in the UK. Constr. Manag. Econ. 2005, 23, 631-644. [CrossRef]

12. Stoneman, P. The Economic Analysis of Technological Change; Oxford University Press: Oxford, UK, 1983.

13. Eriksson, P.E. Exploration and exploitation in project-based organizations: Development and diffusion of knowledge at different organizational levels in construction companies. Int. J. Proj. Manag. 2013, 31, 333-341. [CrossRef]

14. Dubois, A.; Gadde, L. The construction industry as a loosely coupled system: Implications for productivity and innovation. Constr. Manag. Econ. 2002, 20,621-631. [CrossRef]

15. Winch, G. Zephyrs of creative destruction: Understanding the management of innovation in construction. Build. Res. Inf. 1998, 26, 268-279. [CrossRef]

16. Segerstedt, A.; Olofsson, T.; Bankvall, L.; Bygballe, L.E.; Dubois, A.; Jahre, M. Interdependence in supply chains and projects in construction. Suppl. Chain. Manag. Int. J. 2010. [CrossRef]

17. Koskela, L.; Vrijhoef, R. Is the current theory of construction a hindrance to innovation? Build. Res. Inf. 2001, 29, 197-207. [CrossRef]

18. Gann, D.M. Construction as a manufacturing process? similarities and differences between industrialized housing and car production in Japan. Constr. Manag. Econ. 1996, 14, 437-450. [CrossRef]

19. Höök, M.; Stehn, L. Applicability of lean principles and practices in industrialized housing production. Constr. Manag. Econ. 2008, 26, 1091-1100. [CrossRef]

20. Lidelöw, H.; Stehn, L.; Lessing, J.; Engström, D. Industriellt Husbyggande; Studentlitteratur: Lund, Sweden, 2015.

21. Gibb, A.; Isack, F. Re-Engineering through pre-Assembly: Client expectations and drivers. Build. Res. Inf. 2003, 31, 146-160. [CrossRef]

22. Arif, M.; Blismas, N.; Wakefield, R. Drivers, constraints and the future of offsite manufacture in Australia. Constr. Innov. 2009. [CrossRef]

23. Steinhardt, D.A.; Manley, K.; Miller, W. Predicting Australian Builders' Intentions to Use Prefabrication. 2014. Available online: https://eprints.qut.edu.au/81179/1/QUT\%20Housing\%20Project $\% 20-\% 20$ Industry $\%$ 20Paper\%204-eprints.pdf (accessed on 1 March 2020).

24. Pan, W.; Gibb, A.G.; Dainty, A.R. Strategies for integrating the use of off-Site production technologies in house building. J. Constr. Eng. Manag. 2012, 138, 1331-1340. [CrossRef]

25. Steinhardt, D.A.; Manley, K. Adoption of prefabricated housing-The role of country context. Sustain. Cities Soc. 2016, 22, 126-135. [CrossRef] 
26. Barker, K. Review of Housing Supply: Securing Our Future Housing Needs: Interim Report: Analysis; HM Stationery Office: London, UK, 2003.

27. Ball, M.J. The Housebuilding Industry: Promoting Recovery in Housing Supply; Communities and Local Government Publication: London, UK, 2010.

28. Höök, M.; Stehn, L.; Brege, S. The development of a portfolio of business models: A longitudinal case study of a building material company. Constr. Manag. Econ. 2015, 33, 334-348. [CrossRef]

29. Mahapatra, K.; Gustavsson, L. Multi-Storey timber buildings: Breaking industry path dependency. Build. Res. Inf. 2008, 36, 638-648. [CrossRef]

30. Harris, R.; Buzzelli, M. House building in the machine age, 1920s-1970s: Realities and perceptions of modernisation in north America and Australia. Bus. Histor. 2005, 47, 59-85. [CrossRef]

31. Franzini, F.; Toivonen, R.; Toppinen, A. Why not wood? benefits and barriers of wood as a multistory construction material: Perceptions of municipal civil servants from Finland. Buildings 2018, 8, 159. [CrossRef]

32. Chandler, A.D. Strategy and Structure: Chapters in the History of American Industrial Enterprises; MIT Press: Cambridge, MA, USA, 1962.

33. Brege, S.; Stehn, L.; Nord, T. Business models in industrialized building of multi-Storey houses. Constr. Manag. Econ. 2014, 32, 208-226. [CrossRef]

34. Lessing, J.; Brege, S. Business models for product-Oriented house-Building companies-Experience from two Swedish case studies. Constr. Innov. 2015, 15, 449-472. [CrossRef]

35. Lessing, J.; Brege, S. Industrialized building companies' business models: Multiple case study of Swedish and north American companies. J. Constr. Eng. Manag. 2017, 144, 05017019. [CrossRef]

36. Lumpkin, G.T.; Dess, G.G. Clarifying the entrepreneurial orientation construct and linking it to performance. Acad. Manag. Rev. 1996, 21, 135-172. [CrossRef]

37. Child, J. Organizational structure, environment and performance: The role of strategic choice. Sociology 1972, 6,1-22. [CrossRef]

38. Van de Ven, A.H.; Poole, M.S. Explaining development and change in organizations. Acad. Manag. Rev. 1995, 20, 510-540. [CrossRef]

39. Zahra, S.A.; Sapienza, H.J.; Davidsson, P. Entrepreneurship and dynamic capabilities: A review, model and research agenda. J. Manag. Stud. 2006, 43, 917-955. [CrossRef]

40. Zahra, S.A.; George, G. Absorptive capacity: A review, reconceptualization, and extension. Acad. Manag. Rev. 2002, 27, 185-203. [CrossRef]

41. Newey, L.R.; Zahra, S.A. The evolving firm: How dynamic and operating capabilities interact to enable entrepreneurship. Br. J. Manag. 2009, 20, S81-S100. [CrossRef]

42. Wiklund, J.; Shepherd, D. Entrepreneurial orientation and small business performance: A configurational approach. J. Bus. Ventur. 2005, 20, 71-91. [CrossRef]

43. Zahra, S.A.; Covin, J.G. Contextual influences on the corporate entrepreneurship-performance relationship: A longitudinal analysis. J. Bus. Ventur. 1995, 10, 43-58. [CrossRef]

44. Alegre, J.; Chiva, R. Linking entrepreneurial orientation and firm performance: The role of organizational learning capability and innovation performance. J. Small Bus. Manag. 2013, 51, 491-507. [CrossRef]

45. Hart, S.L. An integrative framework for strategy-making processes. Acad. Manag. Rev. 1992, 17, $327-351$. [CrossRef]

46. Rajagopalan, N.; Rasheed, A.M.; Datta, D.K. Strategic decision processes: Critical review and future directions. J. Manag. 1993, 19, 349-384. [CrossRef]

47. Miller, D. The correlates of entrepreneurship in three types of firms. Manag. Sci. 1983, 29, 770-791. [CrossRef]

48. Lieberman, M.B.; Montgomery, D.B. First-Mover (dis) advantages: Retrospective and link with the resource-Based view. Strateg. Manag. J. 1998, 19, 1111-1125. [CrossRef]

49. Gao, Y.; Ge, B.; Lang, X.; Xu, X. Impacts of proactive orientation and entrepreneurial strategy on entrepreneurial performance: An empirical research. Technol. Forecast. Soc. Chang. 2018, 135, 178-187. [CrossRef]

50. Lan, Q.; Wu, S. An empirical study of entrepreneurial orientation and degree of internationalization of small and medium-Sized Chinese manufacturing enterprises. J. Chin. Entrep. 2010, 2, 53-75. [CrossRef]

51. Venkatraman, N. Strategic orientation of business enterprises: The construct, dimensionality, and measurement. Manag. Sci. 1989, 35, 942-962. [CrossRef]

52. Hage, J. Theories of Organizations: Form, Process, and Transformation; Wiley: New York, NY, USA, 1980. 
53. Kimberly, J.R. Managerial innovation. In Handbook of Organizational Design; Nystrom, P.C., Starbuck, W.H., Eds.; Oxford University Press: New York, NY, USA, 1981; Volume 1, pp. 84-104.

54. Miller, D.; Friesen, P.H. Innovation in conservative and entrepreneurial firms: Two models of strategic momentum. Strateg. Manag. J. 1982, 3, 1-25. [CrossRef]

55. Miller, D. Strategy making and structure: Analysis and implications for performance. Acad. Manag. J. 1987, 30, 7-32. [CrossRef]

56. Zahra, S.A.; Covin, J.G. Business strategy, technology policy and firm performance. Strateg. Manag. J. 1993, 14, 451-478. [CrossRef]

57. Gasse, Y. Elaborations on the psychology of the entrepreneur. In Encyclopedia of Entrepreneurship; Kent, C.A., Sexton, D.L., Vesper, K.H., Eds.; Prentice-Hall: Upper Saddle River, NJ, USA, 1982; pp. 57-71.

58. Baird, I.S.; Thomas, H. Toward a contingency model of strategic risk taking. Acad. Manag. Rev. 1985, 10, 230-243. [CrossRef]

59. Miller, D.; Friesen, P.H. Archetypes of strategy formulation. Manag. Sci. 1978, 24, 921-933. [CrossRef]

60. Sitkin, S.B.; Pablo, A.L. Reconceptualizing the determinants of risk behavior. Acad. Manag. Rev. 1992, 17, 9-38. [CrossRef]

61. MacMillan, I.C.; Jones, P.E. Designing organizations to compete. J. Bus. Strategy 1984, 4, 11.

62. Woo, C.Y.; Cooper, A.C. Strategies of effective low share businesses. Strateg. Manag. J. 1981, 2, 301-318. [CrossRef]

63. Cooper, A.C.; Willard, G.E.; Woo, C.Y. Strategies of high performing new and small firms: A reexamination of the niche concept. J. Bus. Ventur. 1986, 1, 247-260. [CrossRef]

64. Porter, M.E. Competitive Advantage of Nations: Creating and Sustaining Superior Performance; Simon and Schuster: New York, NY, USA, 2011.

65. Figueiredo, J.M.d.; Teece, D.J. Mitigating procurement hazards in the context of innovation. Ind. Corp. Chang. 1996, 5, 537-559. [CrossRef]

66. Teece, D.J.; Pisano, G.; Shuen, A. Dynamic capabilities and strategic management. Strateg. Manag. J. 1997, 18, 509-533. [CrossRef]

67. Puffert, D.J. Path dependence in spatial networks: The standardization of railway track gauge. Explor. Econ. Hist. 2002, 39, 282-314. [CrossRef]

68. Liebowitz, S.J.; Margolis, S.E. Path dependence, lock-In, and history. J. Law Econ. Organ. 1995, $205-226$. [CrossRef]

69. Mahoney, J. Path dependence in historical sociology. Theory Soc. 2000, 29, 507-548. [CrossRef]

70. Christensen, C.M. The Innovator's Dilemma: When New Technologies Cause Great Firms to Fail; Harvard Business Review Press: Boston, MA, USA, 2013.

71. Roehrl, R.A.; Riahi, K. Technology dynamics and greenhouse gas emissions mitigation: A cost assessment. Technol. Forecast. Soc. Chang. 2000, 63, 231-261. [CrossRef]

72. Hemström, K.; Gustavsson, L.; Mahapatra, K. The sociotechnical regime and Swedish contractor perceptions of structural frames. Constr. Manag. Econ. 2017, 35, 184-195. [CrossRef]

73. Gosselin, A.; Blanchet, P.; Lehoux, N.; Cimon, Y. Main motivations and barriers for using wood in multi-story and non-Residential construction projects. BioResources 2017, 12, 546-570. [CrossRef]

74. Toppinen, A.; Sauru, M.; Pätäri, S.; Lähtinen, K.; Tuppura, A. Internal and external factors of competitiveness shaping the future of wooden multistory construction in Finland and Sweden. Constr. Manag. Econ. 2019, 37, 201-216. [CrossRef]

75. Hurmekoski, E.; Pykäläinen, J.; Hetemäki, L. Long-Term targets for green building: Explorative delphi backcasting study on wood-Frame multi-Story construction in Finland. J. Clean. Prod. 2018, 172, 3644-3654. [CrossRef]

76. Patchell, J. Linking production and consumption: The coevolution of interaction systems in the Japanese house industry. Ann. Assoc. Am. Geogr. 2002, 92, 284-301. [CrossRef]

77. Teece, D.J. Explicating dynamic capabilities: The nature and microfoundations of (sustainable) enterprise performance. Strateg. Manag. J. 2007, 28, 1319-1350. [CrossRef]

78. Bonev, M.; Wörösch, M.; Hvam, L. Utilizing platforms in industrialized construction: A case study of a precast manufacturer. Constr. Innov. 2015, 15, 84-106. [CrossRef]

79. Yin, R.K. Case Study Research: Design and Methods; Sage Publications: Thousand Oaks, CA, USA, 2013. 
80. Pettigrew, A.M. Longitudinal field research on change: Theory and practice. Organ. Sci. 1990, 1, $267-292$. [CrossRef]

81. Langley, A. Strategies for theorizing from process data. Acad. Manag. Rev. 1999, 24, 691-710. [CrossRef]

82. Geertz, C. Thick description: Toward an interpretive theory of culture. In The Cultural Geography Reader; Oakes, T.S., Price, P.L., Eds.; Routledge: London, UK, 2008; pp. 41-51. [CrossRef]

83. Bennett, A.; Elman, C. Complex causal relations and case study methods: The example of path dependence. Political Anal. 2006, 14, 250-267. [CrossRef]

84. Siggelkow, N. Persuasion with case studies. Acad. Manag. J. 2007, 50, 20. [CrossRef]

85. Mills, A.J.; Durepos, G.; Wiebe, E. Encyclopedia of Case Study Research: L-Z; Index; Sage: Thousand Oaks, CA, USA, 2010.

86. Guest, G.; Bunce, A.; Johnson, L. How many interviews are enough? An experiment with data saturation and variability. Field Methods 2006, 18, 59-82. [CrossRef]

87. Burmeister, E.; Aitken, L.M. Sample size: How many is enough? Aust. Crit. Care 2012, 25, 271-274. [CrossRef]

88. Romney, A.K.; Weller, S.C.; Batchelder, W.H. Culture as consensus: A theory of culture and informant accuracy. Am. Anthropol. 1986, 88, 313-338. [CrossRef]

89. Lundahl, U.; Skärvad, P. Utredningsmetodik för Samhällsvetare och Ekonomer; Studentlitteratur: Lund, Sweden, 2016.

90. Bergström, M. Industrialised Timber Frame Housing Managing Customisation, Change, and Information, Dissertation. Ph.D. Thesis, Luleå University of Technology, Luleå, Sweden, 2004.

91. Björnfot, A. An Exploration of Lean Thinking for Multi-Storey Timber Housing Construction: Contemporary Swedish Practices and Future Opportunities, Dissertation. Ph.D. Thesis, Luleå University of Technology, Luleå, Sweden, 2006.

92. Höök, M. Lean Culture in Industrialized Housing a Study of Timber Volume Element Prefabrication, Dissertation. Ph.D. Thesis, Luleå University of Technology, Luleå, Sweden, 2008.

93. Meiling, J. Continuous Improvement and Experience Feedback in Off-SITE Construction: Timber-Framed Module Prefabrication, Dissertation. Ph.D. Thesis, Luleå University of Technology, Luleå, Sweden, 2010.

94. Jansson, G. Platforms in Industrialised House-Building, Dissertation. Ph.D. Thesis, Luleå University of Technology, Luleå, Sweden, 2013.

95. Westerlund, L. Lindbäcks Husbyggare med Traditioner-Historien om Familjeföretaget Lindbäcks 1924-2009; GTC: Luleå, Sweden, 2009.

96. Björnfot, A.; Jongeling, R. Application of line-Of-Balance and 4D CAD for lean planning. Constr. Innov. 2007, 7, 200-211. [CrossRef]

97. Stehn, L.; Höök, M. Lean principles in industrialized housing production: The need for a cultural change. Lean Constr. J. 2008, 2, 20-33.

98. Johnsson, H.; Meiling, J. Defects in offsite construction: Timber module prefabrication. Constr. Manag. Econ. 2010, 27, 667-681. [CrossRef]

99. Jansson, G.; Johnsson, H.; Engström, D. Platform use in systems building. Constr. Manag. Econ. 2014, 32, 70-82. [CrossRef]

100. Jansson, G.; Schade, J.; Olofsson, T. Requirements management for the design of energy efficient buildings. J. Inf. Technol. Constr. 2013, 18, 321-337.

101. Denzin, N.K. Interpretive Biography; Sage: Thousand Oaks, CA, USA, 1989.

(C) 2020 by the authors. Licensee MDPI, Basel, Switzerland. This article is an open access article distributed under the terms and conditions of the Creative Commons Attribution (CC BY) license (http://creativecommons.org/licenses/by/4.0/). 